African Journal of Biotechnology Vol. 8 (21), pp. 5711-5717, 2 November, 2009

Available online at http://www. academicjournals.org/AJB

DOI: $10.5897 / \mathrm{AJB} 09.793$

ISSN 1684-5315 @ 2009 Academic Journals

Full Length Research Paper

\title{
Growth, nodulation and yield of black gram [ Vigna mungo (L.) Hepper] as influenced by biofertilizers and soil amendments
}

\author{
A. Javaid \\ Institute of Mycology and Plant Pathology, University of the Punjab, Quaid-e-Azam Campus Lahore, Pakistan. \\ E-mail: arshadjpk@yahoo.com.
}

Accepted 7 August, 2009

\begin{abstract}
EM (effective microorganisms) is a commercial biofertilizer mainly consists of photosynthetic and lactic acid bacteria, yeast and actinomycetes. The present study was undertaken to investigate the effect of EM application and two strains of nitrogen fixing Bradyrhizobium japonicum (TAL- 102 and MN-S) on plant growth, nodulation and yield of black gram [Vigna mungo (L.) Hepper] in different soil amendment

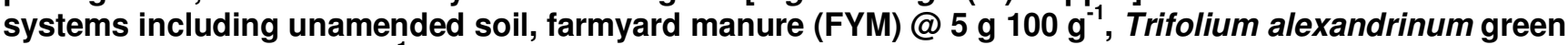

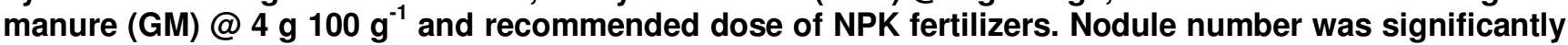
enhanced by inoculation of either of the two B. japonicum strains in NPK and un-amended soils. A marked increase in nodule biomass was also recorded due to $B$. japonicum inoculation in these 2 types of soils. Grain yield was significantly increased by $46 \%$ due to either of the two $B$. japonicum strains in NPK amended soil. EM application markedly enhanced nodule number in FYM amended soil. Conversely, EM application in combination with either of the two $B$. japonicum strains resulted in pronounced reduction both in number and biomass of nodules in NPK fertilizers amendment. EM application significantly enhanced grain yield by $48 \%$ in NPK amendment without $B$. japonicum inoculation.
\end{abstract}

Key words: Black grams, Bradyrhizobium japonicum, effective microorganisms, nitrogen fixation, soil amendments.

\section{INTRODUCTION}

Chemical fertilizers are an indispensable component of today's agriculture. About $60 \%$ of humanity eventually owes its nutritional survival to $\mathrm{N}$ fertilizers (Fixon and West, 2002). However, growing concern about the environmental consequences of mineral $\mathrm{N}$ use and its future cost perspectives emphasize the need to develop new production technologies that are sustainable both economically and ecologically (Khaliq et al., 2006). Organic materials hold great promise as a source of multiple nutrients and ability to improve soil characteristics (Soumare et al., 2003; Moller, 2009). Since the effect of organic nutrients on crop yield is long term and not immediate, thus farmers are reluctant to use organic fertilizers in their cropping system. Use of EM (effective microorganisms) along with organic materials possibly be an effective technique for stimulating release of nutrients from organic sources. EM technology was developed by Dr. Teuro Higa in 1970's at the University of Ryukyus, Okinawa, Japan. Effective microorganisms culture consists of co-existing beneficial microorganisms, the main being the species of photosynthetic bacteria; Rhodopseudomonas plastris and Rhodobacter sphacrodes; lactobacilli such as Lactobacillus plantarum, L. casei and Streptococcus lactis; yeasts (Saccharomyces spp) and Actinomycetes (Strptomyces spp.) which improve crop growth and yield by increasing photosynthesis, producing bioactive substances such as hormones and enzymes, controlling soil diseases and accelerating decomposition of lignin materials in the soil (Higa, 2000; Hussain et al., 2002). When effective micro-organisms cultures are 
applied to the soil they stimulate the decomposition of organic wastes and residues thereby releasing inorganic nutrients for plant uptake. Majority of the scientists who are engaged in promoting this technology have no doubt that plant growth is just as good or batter and quality of plant products is superior to conventional farming (Bajwa et al., 1999a; Iwaishi, 2000; Xu et al., 2000; Javaid, 2006). However, experiences of some workers revealed that the effect of effective microorganisms on crop yield was usually not evident or even negative particularly in the first test crop (Javaid et al., 2008). It is often difficult to establish the predominance of effective microorganisms cultures in soil with only a single application and during only one season. Certain soil properties and the indigenous soil microbial populations are often constraints to the establishment of these microorganisms (Bajwa et al., 1995; Javaid et al., 1997).

Black gram is a grain legume widely cultivated in Pakistan, India and other Asian countries. It is part of diet for millions of people in these countries and a cheep source of protein with $17-34 \%$ of protein in seeds (Gour, 1993). An important feature of the mashbean plant is its ability to establish a symbiotic partnership with specific bacteria, setting up the biological $\mathrm{N}_{2}$-fixation process in root nodules by rhizobia that may supply the plant's needs for N (Mahmood and Athar, 2008; Mandal et al., 2009). The present study was carried out to investigate the effect of two Bradyrhizobium japonicum strains; TAL102 (soybean isolate) and MN-S (mungbean isolate) on growth, nodulation and yield of mashbean and role of EM in improving the efficacy of these strains in different soil amendment systems.

\section{MATERIALS AND METHODS}

\section{Soil characteristics}

Soil used in the experiment was sandy loam in texture having organic matter $0.9 \%, \mathrm{pH} 8.1$, EC $4.8 \mathrm{mS} \mathrm{cm}^{-1}$, nitrogen $0.05 \%$, available phosphorus $14 \mathrm{mg} \cdot \mathrm{kg}^{-1}$ and available potassium 210 mg. $\mathrm{kg}^{-1}$. The micronutrients $\mathrm{Fe}, \mathrm{Cu}$ and $\mathrm{Zn}$ were 9.53, 1.71 and $4.42 \mathrm{mg} \mathrm{kg}^{-1}$ of soil, respectively.

\section{Soil amendments}

This experiment was a continuation of a previous experiment where mungbean [Vigna radiata (L.) Wilczek] was cultivated. Experiment was conducted in earthen pots of $20 \mathrm{~cm}$ diameter and $30 \mathrm{~cm}$ deep. The pot soil was amended either with farmyard manure (FYM) @ 5 $\mathrm{g} / 100 \mathrm{~g}$, Trifolium alexandrianum green manure (GM) @ $4 \mathrm{~g} / 100 \mathrm{~g}$ (on dry weight basis), NPK fertilizers or left unamended. A basal dose of $20 \mathrm{mg} \mathrm{kg}^{-1} \mathrm{~N}$ as urea, $30 \mathrm{mg} \mathrm{kg}^{-1} \mathrm{P}_{2} \mathrm{O}_{5}$ as triple supper phosphate and $30 \mathrm{mg} \mathrm{kg}^{-1} \mathrm{~K}_{2} \mathrm{O}$ as potassium sulphate was supplied to the NPK amended pot soil. Pots were irrigated with tap water of good quality and left for 15 days for decomposition of organic matter. Mungbean was sown in these pots. After harvesting the mungbean crop, the present study was conducted in the same pots.
No more GM and FYM were added for the present study. However, NPK fertilizers were added to the respective pots at the same rate as was for mungbean mentioned above.

\section{Procurement of B. japonicum and EM}

Two peat based $B$. japonicum inocula namely $B$. japonicum st. TAL102 and B. japonicum st. MN-S were obtained from Nuclear Institute for Biotechnology and Genetic Engineering (NIBGE), Faisalabad, Pakistan. B. japonicum st. TAL- 102 is an exotic strain originally isolated from soybean while $B$. japonicum st. MN-S is a local strain isolated from mungbean.

EM stock solution in the commercial name of EM Bioaab was obtained from Nature Farming Research and Development Foundation, Faisalabad, Pakistan. The EM contained high populations of lactic acid bacteria at $1 \times 10^{11} \mathrm{cfu} \mathrm{ml}^{-1}$, photosynthetic bacteria at $1 \times 10^{6} \mathrm{cfu} \mathrm{ml}^{-1}$ and yeast $1 \times 10^{3} \mathrm{cfu} \mathrm{ml}^{-1}$ of suspension (Higa, 2000). The EM stock solution was diluted by adding water in the ratio of $1: 1000$. Respective pots of EM treatments were irrigated with $500 \mathrm{ml}$ of dilute solution of EM (1:1000) 15 days prior to mungbean sowing in the previous experiment. These pots also received $500 \mathrm{~mL}$ of dilute EM solution at fortnight intervals throughout the experimental period for mungbean (previous experiment) as well as for black grams (present experiment).

\section{Treatments and experimental design}

There were 6 treatments in each of the 4 soil amendment systems. These include:

i) Control (without any microbial inoculation).

ii) Effective Microorganisms (EM).

iii) B. japonicum st. MN-S.

iv) B. japonicum st. MN-S + EM.

v) B. japonicum st. TAL- 102.

vi) B. japonicum st. TAL- $102+$ EM.

Black gram seeds were surface sterilized with $1.0 \%$ sodium hypochlorite solution followed by several washings with sterilized water. Seeds were soaked in sterilized water for $2 \mathrm{~h}$ and left in covered petri plates over night to facilitate rapid and uniform germination. Seeds for respective $B$. japonicum treatments were pelted with peat based single strain inocula of $B$. japonicum st. TAL- 102 and $B$. japonicum st. MN-S with concentrated sugar solution as an adhesive. Initially 4 seeds were sown in each pot, which were thinned to 2 uniform seedlings on emergence. Each treatment was replicated 3 times. Pots were arranged in a completely randomized design on a bench in a wire netting house under natural conditions of light and temperature. Plants were irrigated with tap water of good quality whenever required.

\section{Data collection and statistical analysis}

Plants were harvested at flowering and maturity stages. The data regarding shoot length, root and shoot biomass were recorded at both the harvesting stages while that of number and biomass of nodules were recorded only at flowering stage. Data regarding various yield parameters; pod number, pod length, number of seeds per pod and grain yield were recorded at maturity. All the data were analyzed statistically by applying ANOVA followed by Duncan's multiple range test (Steel and Torrie, 1980) to separate the treatment means. 
Table 1. ANOVA for the effect of growth stage, soil amendments, B. japonicum and effective microorganisms (EM) on root and shoot growth of $V$. mungo.

\begin{tabular}{|c|c|c|c|c|}
\hline \multirow{2}{*}{ Sources of variation } & \multirow{2}{*}{ df } & \multicolumn{3}{|c|}{ Mean squares } \\
\hline & & Shoot length & Shoot biomass & Root biomass \\
\hline Treatments & 47 & $87^{\star \star}$ & $4.4^{\star \star}$ & $0.35^{\star \star}$ \\
\hline Growth stage (G) & 1 & $165^{\star \star}$ & $1.32^{\mathrm{ns}}$ & $0.135^{\star *}$ \\
\hline Soil amendments $(A)$ & 3 & $954^{* *}$ & $48.97^{\star *}$ & $20.45^{\star *}$ \\
\hline B. japonicum strains (B) & 2 & $73^{*}$ & $1.40^{\mathrm{ns}}$ & $0.45^{* *}$ \\
\hline EM & 1 & $115^{\star}$ & $10.79^{* *}$ & $1.60^{\star *}$ \\
\hline$G \times A$ & 3 & $9.81^{\mathrm{ns}}$ & $4.81^{\star \star}$ & $0.09^{\star \star}$ \\
\hline$G \times B$ & 2 & $13.7^{\mathrm{ns}}$ & $1.01^{\mathrm{ns}}$ & $0.02^{\mathrm{ns}}$ \\
\hline$G \times E M$ & 6 & $0.34^{\mathrm{ns}}$ & $0.25^{\mathrm{ns}}$ & $0.0005^{\mathrm{ns}}$ \\
\hline$A \times B$ & 6 & $11.1^{\mathrm{ns}}$ & $1.13^{\mathrm{ns}}$ & $0.012^{\mathrm{ns}}$ \\
\hline$A \times E M$ & 1 & $92.1^{* \star}$ & $0.07^{\mathrm{ns}}$ & $0.013^{\mathrm{ns}}$ \\
\hline$B \times E M$ & 3 & $10.4^{\mathrm{ns}}$ & $1.24^{\mathrm{ns}}$ & $0.007^{\mathrm{ns}}$ \\
\hline$G \times A \times B$ & 3 & $22.6^{\mathrm{ns}}$ & $0.95^{\mathrm{ns}}$ & $0.004^{\mathrm{ns}}$ \\
\hline $\mathrm{G} \times \mathrm{A} \times \mathrm{EM}$ & 2 & $10.4^{\mathrm{ns}}$ & $0.29^{\mathrm{ns}}$ & $0.007^{\mathrm{ns}}$ \\
\hline $\mathrm{G} \times \mathrm{B} \times \mathrm{EM}$ & 2 & $17.3^{\mathrm{ns}}$ & $0.30^{\mathrm{ns}}$ & $0.02^{\mathrm{ns}}$ \\
\hline$A \times B \times E M$ & 6 & $19^{\mathrm{ns}}$ & $1.60^{\mathrm{ns}}$ & $0.03^{*}$ \\
\hline$G \times A \times B \times E M$ & 6 & $5.3^{\text {ns }}$ & $0.42^{\mathrm{ns}}$ & $0.04^{*}$ \\
\hline Error & 96 & 15 & 0.65 & \\
\hline Total & 143 & & & \\
\hline
\end{tabular}

*** Significant at $\mathrm{P} \leq 0.01$ and 0.001 , respectively.

\section{RESULTS}

\section{Effect of microbial inoculation on shoot and root growth}

Analysis of variance shows that effect of $B$. japonicum (B) inoculation was significant for shoot length (Table 1). At flowering stage, effect of either of the two $B$. japonicum strains was not much pronounced. However, at maturity stage, both the $B$. japonicum strains markedly enhanced shoot length in un-amended and farmyard manure (FYM) amended soils (Table 2). Both the B. japonicum strains enhanced shoot biomass in NPK amended soil. Effect of $B$. japonicum st. MN-S was more pronounced and significant both at flowering stage and maturity (Table 2). Effect of $B$. japonicum inoculation was also significant for root biomass (Table 1). In green manure (GM) amended soil, both the $B$. japonicum strains markedly suppressed root biomass at maturity stage. By contrast, in NPK amended soil a significant increase in root biomass was recorded by inoculation of either of the two $B$. japonicum strains. In un-amended as well as in FYM amended soil, neither of the two $B$. japonicum strains exhibited pronounced effect on root biomass (Table 2).

Analysis of variance reveals the significant effect of EM application on shoot length and biomass as well as on root biomass. The interactive effect of EM and soil amendment (A) was also significant for shoot length. Similarly, the effect of $A \times B \times E M$ was significant for root biomass (Table 1). The most pronounced and significant effect of EM application was observed on shoot dry biomass in NPK amendment. Similar effect of EM application on root dry biomass was also recorded in NPK amendment at maturity stage. Neither of the two $B$. japonicum strains showed significant response to EM application with respect to root and shoot growth in any of the 4 soil amendment systems (Table 2).

\section{Effect of microbial inoculation on nodulation}

Effect of soil amendments was significant both for number and fresh biomass of nodules (Table 3). The highest nodules number was recorded in un-amended soil followed by NPK amendment. Both the organic amendments resulted in a marked suppression in nodules number. Adverse effect was more pronounced due to GM than FYM amendment (Table 4).

$B$. japonicum inoculation showed a significant effect on nodulation. Nodules number was significantly enhanced by both the $B$. japonicum strains in un-amended as well as in NPK amended soil. B. japonicum st. MN-S was more effective in un-amended soil while st. TAL-102 was more effective in NPK amendment. Effect of inoculation 
Table 2. Effect of $B$. japonicum and EM application on plant vegetative growth in $V$. mungo.

\begin{tabular}{|c|c|c|c|c|c|c|}
\hline \multirow[b]{2}{*}{ Treatments } & \multicolumn{3}{|c|}{ Flowering stage } & \multicolumn{3}{|c|}{ Maturity stage } \\
\hline & $\begin{array}{c}\text { Shoot } \\
\text { length }(\mathrm{cm})\end{array}$ & $\begin{array}{c}\text { Shoot dry } \\
\text { wt. (g) }\end{array}$ & $\begin{array}{c}\text { Root dry } \\
\text { wt. (g) }\end{array}$ & $\begin{array}{c}\text { Shoot } \\
\text { length }(\mathrm{cm})\end{array}$ & $\begin{array}{c}\text { Shoot dry } \\
\text { wt. (g) }\end{array}$ & $\begin{array}{c}\text { Root dry } \\
\text { wt. (g) }\end{array}$ \\
\hline \multicolumn{7}{|l|}{ Un-amended soil } \\
\hline Control & $33 \mathrm{a}-\mathrm{g}$ & $3.6 b-f$ & $0.52 \mathrm{ab}$ & $31 \mathrm{c}-\mathrm{g}$ & 2.9 e-h & $0.53 \mathrm{~b}-\mathrm{e}$ \\
\hline EM & $37 a-c$ & $4.4 \mathrm{a}-\mathrm{c}$ & $0.53 a b$ & $40 a b$ & $3.7 \mathrm{c}-\mathrm{f}$ & $0.70 \mathrm{ab}$ \\
\hline B. japonicum st. MN-S & 35 a-e & $4.6 \mathrm{a}-\mathrm{c}$ & $0.64 \mathrm{a}$ & $38 \mathrm{a}-\mathrm{c}$ & $3.6 \mathrm{~d}-\mathrm{f}$ & $0.60 \mathrm{~b}-\mathrm{e}$ \\
\hline B. japonicum st. MN-S + EM & $39 a$ & $5.0 \mathrm{ab}$ & $0.54 \mathrm{ab}$ & $40 a b$ & $3.6 \mathrm{~d}-\mathrm{f}$ & $0.63 \mathrm{bc}$ \\
\hline B. japonicum st. TAL- 102 & 35 a-e & $4.1 \mathrm{a}-\mathrm{d}$ & $0.46 \mathrm{~b}-\mathrm{d}$ & $37 \mathrm{a}-\mathrm{d}$ & $3.0 \mathrm{e}-\mathrm{h}$ & $0.64 \mathrm{bc}$ \\
\hline B. japonicum st. TAL- 102 + EM & $38 a b$ & $4.0 \mathrm{a}-\mathrm{e}$ & $0.50 \mathrm{a}-\mathrm{c}$ & $40 a b$ & $4.6 \mathrm{a}-\mathrm{e}$ & $0.54 \mathrm{~b}-\mathrm{e}$ \\
\hline \multicolumn{7}{|l|}{ Farmyard manure } \\
\hline Control & $32 \mathrm{a}-\mathrm{g}$ & $2.2 \mathrm{~g}-\mathrm{i}$ & $0.14 \mathrm{~g}$ & $34 \mathrm{~b}-\mathrm{e}$ & $3.5 \mathrm{~d}-\mathrm{g}$ & $0.22 \mathrm{~d}-\mathrm{g}$ \\
\hline EM & $29 d-i$ & $2.7 \mathrm{~d}-\mathrm{i}$ & $0.20 \mathrm{e}-\mathrm{g}$ & $30 \mathrm{~d}-\mathrm{h}$ & $3.5 \mathrm{~d}-\mathrm{g}$ & $0.30 \mathrm{f}-\mathrm{i}$ \\
\hline B. japonicum st. MN-S & $30 \mathrm{c}-\mathrm{h}$ & $1.7 \mathrm{hi}$ & $0.16 \mathrm{fg}$ & $40 a b$ & $3.1 \mathrm{e}-\mathrm{h}$ & $0.20 \mathrm{~h}-\mathrm{j}$ \\
\hline B. japonicum st. MN-S + EM & $32 \mathrm{~b}-\mathrm{g}$ & $2.24 \mathrm{f}-\mathrm{i}$ & $0.21 \mathrm{e}-\mathrm{g}$ & 36 a-e & $3.7 \mathrm{c}-\mathrm{f}$ & $0.38 \mathrm{e}-\mathrm{h}$ \\
\hline B. japonicum st. TAL- 102 & $35 a-d$ & $2.8 \mathrm{~d}-\mathrm{h}$ & $0.21 \mathrm{e}-\mathrm{g}$ & $38 \mathrm{a}-\mathrm{c}$ & $2.9 \mathrm{e}-\mathrm{h}$ & $0.25 \mathrm{~g}-\mathrm{j}$ \\
\hline B. japonicum st. TAL- $102+$ EM & $36 a-c$ & $3.5 \mathrm{c}-\mathrm{g}$ & $0.32 d-f$ & $34 \mathrm{~b}-\mathrm{e}$ & $3.6 \mathrm{~d}-\mathrm{f}$ & $0.44 \mathrm{c}-\mathrm{g}$ \\
\hline \multicolumn{7}{|l|}{ Green manure } \\
\hline Control & $24 \mathrm{~h}-\mathrm{j}$ & $1.3 \mathrm{i}$ & $0.10 \mathrm{~g}$ & $29 d-h$ & $2.3 \mathrm{f}-\mathrm{i}$ & $0.19 \mathrm{~h}-\mathrm{j}$ \\
\hline EM & $22 j$ & $1.55 \mathrm{hi}$ & $0.15 \mathrm{~g}$ & $26 \mathrm{f}-\mathrm{h}$ & $1.9 \mathrm{~g}-\mathrm{i}$ & $0.19 \mathrm{~h}-\mathrm{j}$ \\
\hline B. japonicum st. MN-S & $23 \mathrm{ij}$ & $2.0 \mathrm{hi}$ & $0.09 \mathrm{~g}$ & $25 \mathrm{gh}$ & $1.3 \mathrm{i}$ & $0.09 \mathrm{ij}$ \\
\hline B. japonicum st. MN-S + EM & $29 f-j$ & $2.2 \mathrm{~g}-\mathrm{i}$ & $0.21 \mathrm{e}-\mathrm{g}$ & $29 d-h$ & $2.3 \mathrm{f}-\mathrm{i}$ & $0.14 \mathrm{ij}$ \\
\hline B. japonicum st. TAL- 102 & $29 e-j$ & $1.5 \mathrm{hi}$ & $0.10 \mathrm{~g}$ & $23 \mathrm{~h}$ & $1.3 i$ & $0.08 \mathrm{j}$ \\
\hline B. japonicum st. TAL- $102+$ EM & $26 g-j$ & $2.6 \mathrm{e}-\mathrm{i}$ & $0.12 \mathrm{~g}$ & $26 \mathrm{f}-\mathrm{h}$ & $1.8 \mathrm{hi}$ & $0.13 \mathrm{ij}$ \\
\hline \multicolumn{7}{|l|}{ NPK fertilizers } \\
\hline Control & $34 a-f$ & $2.8 d-i$ & $0.34 \mathrm{c}-\mathrm{e}$ & $33 b-f$ & $3.6 \mathrm{~d}-\mathrm{f}$ & $0.46 c-f$ \\
\hline EM & $35 a-f$ & $4.4 \mathrm{a}-\mathrm{c}$ & $0.42 b-d$ & $39 a b$ & $5.7 \mathrm{a}$ & $0.90 \mathrm{a}$ \\
\hline B. japonicum st. MN-S & $33 a-f$ & $5.4 \mathrm{a}$ & $0.35 \mathrm{c}-\mathrm{e}$ & $36 a-e$ & $5.4 \mathrm{~b}$ & $0.72 \mathrm{~b}$ \\
\hline B. japonicum st. MN-S + EM & $38 a b$ & $4.5 \mathrm{a}-\mathrm{c}$ & $0.46 \mathrm{~b}-\mathrm{d}$ & $40 a b$ & $4.9 \mathrm{a}-\mathrm{d}$ & $0.57 \mathrm{~b}-\mathrm{e}$ \\
\hline B. japonicum st. TAL- 102 & $33 a-g$ & $3.7 \mathrm{~b}-\mathrm{f}$ & $0.34 \mathrm{a}$ & 36 a-e & $4.1 \mathrm{~b}-\mathrm{e}$ & $0.69 \mathrm{ab}$ \\
\hline B. japonicum st. TAL- $102+\mathrm{EM}$ & $37 a-c$ & $4.2 \mathrm{a}-\mathrm{d}$ & $0.55^{\mathrm{ns}}$ & $43 \mathrm{a}$ & $5.3 a-c$ & $0.57 \mathrm{~b}-\mathrm{d}$ \\
\hline
\end{tabular}

In a column, values with different letters in a column show significant difference at $P \leq 0.05$ as determined by Duncan's multiple range test.

on nodules biomass was also much pronounced in these two types of soils. Conversely, inoculation of either of the two $B$. japonicum strains failed to show significant effect on number and biomass of nodules in GM and FYM amended soils (Table 4).

Effect of EM application on nodulation was variable with respect to soil amendments. Analysis of variance shows that the interactive effect of EM and soil amendments was highly significant $(P \leq 0.01$ and 0.001$)$ both for nodule number and biomass (Table 3). In FYM amended soil, EM application markedly enhanced nodule number both in $B$. japonicum inoculated and un-inoculated treatments. In contrast to that, in NPK amendment, EM application suppressed number as well as biomass of nodules in $B$. japonicum inoculated plants. In other soil amendment systems, effect of EM application on nodulation was not much pronounced (Table 4).

\section{Effect of microbial inoculation on yield}

Analysis of variance shows that effect of soil amendments was significant for various yield parameters; number of pods per plants, pod length, number of seeds per pod and grain yield (Table 3). Generally, values of these parameters were lower in GM amendment as compared to other soil amendment systems (Table 4). B. japonicum st. MN-S enhanced number of pods per plant by $26 \%$ in un-amended soil. By contrast, both the species reduced pod number by $40 \%$ in GM amendment. However, all the effects were insignificant statistically. Effect of $B$. japonicum inoculation on pod length and number of seeds per pod was also insignificant in all the 4 soil amendment systems. Grain yield was significantly enhanced by $46 \%$ due to each of the two $B$. japonicum strains in NPK amended soil. EM application resulted in significant 
Table 3. ANOVA for the effect of soil amendments, B. japonicum and effective microorganisms (EM) on nodulation and yield characteristics of Vi. mungo.

\begin{tabular}{|c|c|c|c|c|c|c|c|}
\hline \multirow[b]{2}{*}{ Trait } & \multirow[b]{2}{*}{ df } & \multicolumn{6}{|c|}{ Mean Squares } \\
\hline & & $\begin{array}{c}\text { Nodule } \\
\text { no. }\end{array}$ & $\begin{array}{l}\text { Nodule } \\
\text { fresh wt. }\end{array}$ & Pod no. & Pod length & Seed/pod & Grain yield \\
\hline Treatments & 23 & $8190^{\star \star *}$ & $0.14^{\star * *}$ & $58^{\star \star \star}$ & $0.15^{\star \star \star}$ & $0.95^{\star * *}$ & $2.0^{\star * *}$ \\
\hline Soil amendments (A) & 3 & $48708^{\star \star \star}$ & $0.723^{\star \star *}$ & $296^{\star \star \star}$ & $0.63^{\star *}$ & $4.26^{\star \star *}$ & $11.9^{\star \star \star}$ \\
\hline B. japonicum strains (B) & 2 & $4629^{\star *}$ & $0.063^{*}$ & $4.5^{\mathrm{ns}}$ & $0.11^{\mathrm{ns}}$ & $0.44^{\mathrm{ns}}$ & $0.019^{\mathrm{ns}}$ \\
\hline EM & 1 & $15^{\mathrm{ns}}$ & $0.030^{\mathrm{ns}}$ & $40.5^{\mathrm{ns}}$ & $0.051^{\mathrm{ns}}$ & $0.015^{\mathrm{ns}}$ & $0.809^{\mathrm{ns}}$ \\
\hline$A \times B$ & 6 & $1575^{\mathrm{ns}}$ & $0.028^{\text {ns }}$ & $32.4^{\mathrm{ns}}$ & $0.059^{\text {ns }}$ & $0.089^{\text {ns }}$ & $0.753^{*}$ \\
\hline$A \times E M$ & 3 & $4444^{\star \star}$ & $0.195^{\star \star *}$ & $22.6^{\mathrm{ns}}$ & $0.033^{\mathrm{ns}}$ & $0.617^{\mathrm{ns}}$ & $0.75^{\mathrm{ns}}$ \\
\hline$B \times E M$ & 2 & $1312^{\mathrm{ns}}$ & $0.068^{\star}$ & $24.0^{\mathrm{ns}}$ & $0.107^{\mathrm{ns}}$ & $1.498^{* *}$ & $0.071^{\mathrm{ns}}$ \\
\hline$A \times B \times E M$ & 6 & $1262^{\mathrm{ns}}$ & $0.014^{\mathrm{ns}}$ & $12.5^{\mathrm{ns}}$ & $0.095^{\mathrm{ns}}$ & $0.466^{\mathrm{ns}}$ & $0.536^{\mathrm{ns}}$ \\
\hline Error & 48 & 901 & 0.02 & 15.8 & 0.065 & 0.332 & 0.327 \\
\hline Total & 71 & & & & & & \\
\hline
\end{tabular}

${ }^{*},{ }^{* *},{ }^{* * *}$, significant at $\mathrm{P} \leq 0.05,0.01$ and 0.001 , respectively; ns: Non significant.

increase of $48 \%$ in grain yield in NPK amended soil. In general, effect of EM application on various yield parameters was insignificant (Tables 3 and 4).

\section{DISCUSSION}

In the present study, suitability of cross inoculation of two $B$. japonicum strains; TAL-102 (soybean isolate) and MN$S$ (mungbean isolate) inoculation to mashbean for bather growth, yield and nodulation characteristics was studied in different soil amendment systems. Both the strains proved suitable for mashbean. However, the affectivity of the two inoculated strains was associated with the type of soil amendment. Nodule number was significantly increased by inoculation of either of the two strains in NPK amendment. Nodule biomass was also markedly enhanced in inoculated treatments in this soil amendment system. As a consequence of improved nodulation, a similar significant improvement in grain yield was also evident due to inoculated $B$. japonicum strains. Earlier, Dubey (1998) obtained highest grain yield in soybean when host plant was inoculated with Bradyrhizobium in combination with NPK fertilizers. In the present study, response of nodulation to $B$. japonicum strains inoculation in un-amended soil was similar to that of response in NPK fertilizers amendments. However, unlike that of NPK fertilizer amendment, grain yield was not enhanced in unamended soil in response to $B$. japonicum inoculation. Earlier, Mahmood and Athar (2008) reported that cross inoculation of mashbean with rhizobia isolated from Dalbergia sissoo, Leucaena leucocephala, Pithecellobium dulce, Prosopis cineraria, Prosopis glandulosa and Prosopis juliflora significantly enhanced dry weight and nitrogen contents of mashbean. In the present study, in both the organic matter amendments; farmyard and green manure amended soils, nodulation was very poor as compared to NPK amended and un-amended soils. Inoculation of both the $B$. japonicum strains failed to enhance nodulation in these two organic matters amended soils.

Effect of EM application on nodulation was variable in different soil amendment systems. EM application markedly enhanced nodule number both in $B$. japonicum inoculated and un-inoculated treatments in FYM amended soil. Conversely, in NPK amendment, EM application adversely affected the nodulation both in terms of number and biomass. In GM amendment as well as in unamended soil, effect of EM application was not pronounced. Earlier reports regarding the effect of EM application on nodulation are also contradictory. EM application caused a significant reduction in nodule number but increased the size and biomass of nodules in Trifolium alexand rinum (Bajwa et al., 1999b). By contrast, Javaid et al. (2000) noted a significant increase in nodulation in Vigna radiata due to EM application. Javaid et al. (2002) have reported similar effects of long-term EM application and organic manures on nodulation in Phaseolus vulgaris L. In seems probable that soil amendments as well as indigenous population of soil microorganisms determine the nodulation response of host plant to EM application.

Similar to that of nodulation, effect of EM application on plant growth and yield was also variable in different soil amendments. The most pronounced and significant effect of EM application on shoot and root dry biomass was observed in NPK amendment. Likewise, EM application resulted in $48 \%$ increase in grain yield in NPK amended soil without $B$. japonicum inoculation. In rest of the treatments, effect of EM application was not much pronounced. Earlier there are contradictory reports regarding 
Table 4. Effect of $B$. japonicum and EM application on nodulation and yield of $V$. mungo.

\begin{tabular}{|c|c|c|c|c|c|c|}
\hline Treatments & $\begin{array}{c}\text { Nodule } \\
\text { no. }\end{array}$ & $\begin{array}{c}\text { Nodule } \\
\text { fresh wt. (g) }\end{array}$ & Pod no. & $\begin{array}{c}\text { Pod } \\
\text { length } \\
(\mathrm{cm})\end{array}$ & Seed/pod & $\begin{array}{c}\text { Grain yield } \\
\text { (g) }\end{array}$ \\
\hline \multicolumn{7}{|l|}{ Un-amended soil } \\
\hline Control & $116 \mathrm{f}$ & $0.38 \mathrm{c}-\mathrm{g}$ & $17 \mathrm{a}-\mathrm{f}$ & $3.75 \mathrm{a}$ & $5 a b$ & $2.8 \mathrm{a}$ \\
\hline EM & $97 \mathrm{c}-\mathrm{f}$ & $0.45 b-f$ & 18 a-e & $3.64 \mathrm{a}$ & $5 a b$ & $2.9 \mathrm{a}$ \\
\hline B. japonicum st. MN-S & $175 a b$ & $0.54 a-d$ & $23 \mathrm{a}$ & $3.47 \mathrm{a}$ & $4 a-d$ & $3.1 \mathrm{a}$ \\
\hline B. japonicum st. MN-S + EM & $188 \mathrm{a}$ & $0.73 \mathrm{a}$ & 16 a-f & $3.51 \mathrm{a}$ & $4 \mathrm{a}-\mathrm{d}$ & $2.3 \mathrm{ab}$ \\
\hline B. japonicum st. TAL-102 & $158 \mathrm{ac}$ & $0.61 \mathrm{a}-\mathrm{d}$ & 16 a-f & $3.60 \mathrm{a}$ & $5 a b$ & $2.3 a b$ \\
\hline B. japonicum st. TAL-102 + EM & 142 a-e & $0.55 a-d$ & 16 a-f & $3.61 \mathrm{a}$ & 4 a-d & $2.2 \mathrm{a}-\mathrm{c}$ \\
\hline \multicolumn{7}{|l|}{ Farmyard manure } \\
\hline Control & $76 \mathrm{f}-\mathrm{i}$ & $0.14 \mathrm{gh}$ & $12 c-g$ & $3.4 \mathrm{a}$ & $4.4 \mathrm{a}-\mathrm{c}$ & $1.4 \mathrm{~b}-\mathrm{d}$ \\
\hline EM & $106 \mathrm{~b}-\mathrm{f}$ & $0.18 \mathrm{gh}$ & $12 c-g$ & $3.4 \mathrm{a}$ & $4.3 \mathrm{a}-\mathrm{d}$ & $1.2 \mathrm{c}-\mathrm{d}$ \\
\hline B. japonicum st. MN-S & $72 \mathrm{f}-\mathrm{i}$ & $0.09 \mathrm{~h}$ & $11 d-g$ & $3.2 \mathrm{a}$ & $3.6 \mathrm{~b}-\mathrm{e}$ & $0.9 \mathrm{~d}$ \\
\hline B. japonicum st. MN-S + EM & $123 a-f$ & 0.24 e-h & 10 e-g & $3.3 \mathrm{a}$ & $4.2 \mathrm{a}-\mathrm{d}$ & $1.2 \mathrm{~cd}$ \\
\hline B. japonicum st. TAL-102 & 82 e-h & $0.18 \mathrm{gh}$ & $13 \mathrm{~b}-\mathrm{g}$ & $3.4 \mathrm{a}$ & $4.0 \mathrm{~b}-\mathrm{e}$ & $1.5 b-d$ \\
\hline B. japonicum st. TAL-102 + EM & $116 b-f$ & $0.16 \mathrm{gh}$ & $20 \mathrm{ab}$ & $3.5 \mathrm{a}$ & $4.1 \mathrm{a}-\mathrm{d}$ & $2.2 \mathrm{a}-\mathrm{c}$ \\
\hline \multicolumn{7}{|l|}{ Green manure } \\
\hline Control & $19 \mathrm{i}$ & $0.55 a-d$ & 10 e-g & $3.4 \mathrm{a}$ & $3.2 \mathrm{de}$ & $1.0 \mathrm{~d}$ \\
\hline EM & $25^{\text {hi }}$ & $0.66 a b$ & 10 e-g & $3.2 \mathrm{a}$ & $3.6 \mathrm{~b}-\mathrm{e}$ & $1.1 \mathrm{~d}$ \\
\hline B. japonicum st. MN-S & $19 i$ & 0.50 a-e & $6 \mathrm{~g}$ & $2.7 \mathrm{a}$ & $2.8 \mathrm{e}$ & $0.6 \mathrm{~d}$ \\
\hline B. japonicum st. MN-S + EM & $30 \mathrm{~g}-\mathrm{i}$ & $0.60 \mathrm{a}-\mathrm{d}$ & 10 e-g & $3.3 \mathrm{a}$ & $3.7 \mathrm{~b}-\mathrm{e}$ & $1.2 \mathrm{~cd}$ \\
\hline B. japonicum st. TAL-102 & 22 hi & $0.70 \mathrm{ab}$ & $6 \mathrm{~g}$ & $3.1 \mathrm{a}$ & $3.4 \mathrm{c}-\mathrm{e}$ & $0.6 \mathrm{~d}$ \\
\hline B. japonicum st. TAL-102 + EM & $19 \mathrm{i}$ & $0.65 a-c$ & 10 e-g & $3.1 \mathrm{a}$ & $3.4 c-e$ & $1.0 \mathrm{~d}$ \\
\hline \multicolumn{7}{|l|}{ NPK fertilizers } \\
\hline Control & $87 \mathrm{~d}-\mathrm{g}$ & $0.38 \mathrm{~d}-\mathrm{g}$ & $13 \mathrm{~b}-\mathrm{g}$ & $3.2 \mathrm{a}$ & $4.1 \mathrm{a}-\mathrm{d}$ & $1.4 \mathrm{~d}$ \\
\hline EM & 109 b-f & 0.24 e-h & 16 a-f & $3.5 \mathrm{a}$ & $4.6 \mathrm{ab}$ & $2.7 \mathrm{a}$ \\
\hline B. japonicum st. MN-S & 149 a-d & $0.60 \mathrm{a}-\mathrm{d}$ & $17 a-f$ & $3.4 \mathrm{a}$ & $4.3 \mathrm{a}-\mathrm{c}$ & $2.6 \mathrm{a}$ \\
\hline B. japonicum st. MN-S + EM & $100 \mathrm{~b}-f$ & $0.24 \mathrm{e}-\mathrm{h}$ & $20 a-c$ & $3.5 \mathrm{a}$ & $4.3 a-c$ & $2.9 \mathrm{a}$ \\
\hline B. japonicum st. TAL-102 & $163 a b$ & $0.76 b-f$ & $11 \mathrm{~d}-\mathrm{g}$ & $3.7 \mathrm{a}$ & $5.1 \mathrm{a}$ & $2.6 \mathrm{a}$ \\
\hline B. japonicum st. TAL-102 + EM & $78 \mathrm{f}-\mathrm{i}$ & $0.20 \mathrm{f}-\mathrm{h}$ & $18 \mathrm{a}-\mathrm{d}$ & $3.3 \mathrm{a}$ & $3.4 \mathrm{c}-\mathrm{e}$ & $2.4 \mathrm{a}$ \\
\hline
\end{tabular}

In a column, values with different letters in a column show significant difference at $P \leq 0.05$ as determined by Duncan's multiple range test.

the effect of EM application on crop growth and yield. Many workers have reported increase in crop growth and yield by the application of EM (Daly and Stewart, 1999; Yan and Xu, 2002; Javaid, 2006; Khaliq et al., 2006). However, the investigations of other workers have revealed that the effect of EM on crop growth and yield was usually not evident or even negative especially in the first test crop (Bajwa et al., 1995, 1999b; Diass et al., 2008; Javaid et al., 2008). Certain soil properties and the indigenous soil microbial populations are often constraints to the establishment of EM cultures. Studies have shown that these constrains can be overcome through periodic repeated applications of EM at least during the first few years (Sangakkara et al., 1998; Javaid et al., $2000,2002)$. According to Kinjo et al. (2000) the lack of consistency in results of the experiments regarding EM application may be due to variable cultural conditions employed in previous studies. Imai and Higa (1994) stated that the observed decline in crop yields could often be attributed to the fact that soils, where conventional farming is practiced, have become disease-inducing or putrefactive soils from long-term use of pesticides and chemical fertilizers. Consequently, it takes time to establish a disease-suppressive or zymogenic soil. Until this conversion process is completed, it is virtually impossible to exceed crop yields that were obtained with conventional farming methods. However, the present study reveals that the effect of EM application on crop growth and yield is associated with the type of soil amendment used. This study concludes that the benefits of $B$. japonicum strains TAL- 102 and MN-S and EM to black gram can be best exploited by applying these biofertili- 
zers in NPK amended soils. However, further field trials are required before these findings are recommended to the farmers for field application of these biofertlizers.

\section{ACKNOWLEDGEMENTS}

Prof. Dr Tahir Hussain, Director Nature Farming Research Centre Faisalabad provided EM solution and Dr. Fouzia Yousaf Hafeez, NIBGE Pakistan provided $B$. japonicum cultures.

\section{REFERENCES}

Bajwa R, Javaid A, Tasneem Z (1995). Response of indigenous soil microflora to EM inoculation in Pakistan. Biota 1: 73-79.

Bajwa R, Javaid A, Haneef B (1999a). EM and VAM Technology in Pakistan V: Response of chickpea (Cicer arietinum L.) to coinoculation of effective microorganisms (EM) and VA mycorrhiza under allelopathic stress. Pak. J. Bot. 31: 387-396.

Bajwa R,Javaid A, Rabbani N (1999b). EM and VAM technology in Pakistan. Effect of organic amendments and EM on VA mycorrhiza, nodulation and crop growth in Trifolium alexandrianum L. Pak. J. Biol. Sci. 2: 590-593.

Daly MJ, Stewart DPC (1999). Influence of "effective microorganisms" (EM) on vegetative production and carbon mineralization- a preliminary investigation. J. Sustain Agric. 14: 15-25.

Diass N, Lobo MG, Socorro AR, Bruckner U, Heller J, Gonzalez M (2008). The effect of three organic pre-harvest treatments on Swiss chard (Beta vulgaris L. var. cycla L.) quality. Eur. Food Res. Technol. 226: 345-353.

Dubey SK (1998). Response of soybean (Glycine max) to biofertilizers with and without nitrogen, phosphorus and potassium on swell-shrink soil. Indian J. Agron. 43: 546-549.

Gour YD (1993). Microbiology, physiology and agronomy of nitrogen fixation: Legume-Rhizobium symbiosis. Proc. Indian Nat. Sci. Acad. B 59: 333-358.

Higa T (2000). What is EM technology? EM World J. 1: 1-6.

Hussain T, Anjum AD, Tahir J (2002). Technology of beneficial microorganisms. Nature Farm Environ. 3: 1-14.

Imai S, Higa T (1994). Kyusei nature farming in Japan. Effect of EM on growth and yield of spinach. In: Proceedings of 2nd International Conference on Kyusei Nature Farming, Brazil, Oct. 7-11, 1991. pp. 92-96.

Iwaishi S (2000). Effect of organic fertilizer and effective microorganisms on growth, yield and quality of paddy-rice varieties. J. Crop Prod. 3: 269-273
Javaid A (2006). Foliar application of effective microorganisms on pea as an alternative fertilizer. Agron. Sustain Dev. 26: 257-262

Javaid A, Bajwa R, Ahmad Q, Rabbani N (1997). Effect of EM application on growth, yield, nodulation and nitrogen nutrition in pea (Pisum sativum L.) in heat sterilized and unsterilized soil. Sci. Int. (Lahore) 9: 307-309.

Javaid A, Bajwa R, Rabbani N, Uzma M (2000). EM and VAM technology in Pakistan. IX: Effect of EM application on growth, yield, nodulation and VA mycorrhizal colonization in Vigna radiata (L) Wilczek. Pak. J. Biol. Sci. 3: 694-698.

Javaid A, Anjum T, Bajwa R (2002). EM and VAM technology in Pakistan. XII: Growth, nodulation and VA mycorrhizal response of Phaseolus vulgaris to long-term EM application. Pak. J. Phytopathol. 14: 57-61.

Javaid A, Bajwa R, Anjum T (2008). Effect of heat sterilization and EM (effective microorganisms) application of wheat (Triticum aestivum L.) grown in organic matter amended soils. Cereal Res. Commun. 36: 489-499.

Khaliq A, Abbasi MK, Hussain T (2006). Effect of integrated use of organic and inorganic nutrient sources with effective microorganisms (EM) on seed cotton yield in Pakistan. Bioresour. Technol. 97: 967972.

Kinjo T, Perez K, de Almeida E, Ramos MAG, Oliveia de JO (2000). Plant growth affected by EM-Bokashi and chemical fertilizers. Nature Farm Environ. 1: 33-38.

Mahmood A, Athar M (2008). Cross inoculation studies: Response of Vigna mungo to inoculation with rhizobia from tree legumes growing under arid Environment. Int. J. Environ. Sci. Technol. 5: 135-139.

Mandal S, Mandal M, Das A (2009). Stimulation of indoleacetic acid production in a Rhizobium isolate of Vigna mungo by root nodule phenolic acids. Arch. Microbiol. 191: 389-393.

Moller K (2009). Influence of different manuring systems with and without biogas digestion on soil organic matter and nitrogen inputs, flows and budgets in organic cropping systems. Nutr. Cycling Agroecosyst. 84: 179-202.

Sangakkara UR, Marambe B, Attanayake AMU, Piyadasa ER (1998). Nutrient use efficiency of selected crops grown with effective microorganisms in organic systems. In: Proceedings of $4^{\text {th }}$ International Conference on Kysei Nature Farming held in Paris, France, June 19-21, 1995. pp. 111-117.

Xu HL, Wang R, Mridha MAU (2000). Effects of organic fertilizers and a microbial inoculant on leaf photosynthesis and fruit yield and quality of tomato plants. J. Crop Prod. 3: 173-182.

Yan PS, Xu HL (2002). Influence of EM Bokashi on nodulation, physiological characters and yield of peanut in nature farming fields. J. Sustain Agric. 19: 105-112. 